Futó Péter és Szeszler Zsuzsa

\title{
A településfejlesztési koncepció készítésének módszerei az EU-ban és Magyarországon*
}

\section{A településfejlesztési koncepció elkészítése}

\section{A TERVEZÉSI FOLYAMAT}

A fejlesztési terv, stratégia vagy koncepció elkészítése és megvalósítása az alábbi részfeladatokra bontható:

- a tervezó csoport megszervezése;

- idóbeli terv elkészítése;

- az érdekeltek és intézményi szereplók figyelmének felkeltése;

- az érdekeltek folyamatos részvételének biztosítása;

- a projekt strukturálása: a felelós intézmények/személyek kijelölése, a jogkörök, az intézményi struktúrák, a finanszírozás tisztázása.

Mivel a döntéseket a képviselótestület hozza, a képviselóket fel kell készíteni a fejlesztésre. Egyes településeken és egyszerúbb projektek esetén elegendó a figyelmet felhívni és a koncepcióval kapcsolatos érzékenységet kialakítani (ún. szenzibilizálás). Más településeken és bonyolultabb projektek esetén szakirodalmat kell eljuttatni a képviselókhöz, vagy képzési programot kell indítani a testület tagjai számára.

Mivel a hosszú távú tervezésnek számos alternatívát kell figyelembe venni, ezért az elókészító folyamat során sok közösségben bevált az „ötletbörze” (brainstorming) nevú döntéselókészító technika. Ez egy olyan csoportfoglalkozás, melynek során a szakértók és a helyi érdekeltek egy vezetó tanácsadó vagy tréner segítségével a hétköznapi gondolkodáshoz, elemzéshez képest sokkal szabadabban, de a realitásoktól mégsem teljesen elszakadva képzelik el a település jövójét.

* Eredetileg megjelent: TÖOSZ Módszertani füzetek, 2003/2. Budapest: ÖnkorPress Kiadó: 16-27. 
A tervezési munka fontos mérföldköve a településfejlesztési dokumentáció elkészítése. Ezzel azonban a tervezésnek nincs vége, hiszen a továbbiakban folyamatosan ellenórizni kell a tervek megvalósítását, és a feltételek módosulása esetén a terveket is meg kell változtatni. A koncepcióban hosszú távú célok jelennek meg, és ezeket állandóan ütköztetni és egyeztetni kell a változó valósággal. Az eredeti koncepció megváltozása nem baj, só́t abba a változtathatóságot eleve be kell építeni.

A fejlesztési terv, illetve a településfejlesztési koncepció elkészítése során egyszerúbb esetben támaszkodni lehet azokra a hagyományokra, amelyek az önkormányzatban már kialakultak hasonló projektek elókészítése során. A legtöbb településen a vezetók tisztában vannak az önkormányzat adminisztratív, szervezési és szakmai kapacitásával, és pontosan tudják, hogy mely részfeladatokat kell belsó szakemberekkel és melyeket külsó tanácsadókkal, tervezókkel elvégeztetni. Kissé bonyolultabb esetekben azonban, ha a projekt meghalad egy bizonyos komplexitási szintet, akkor érdemes segítségül hívni a projektmenedzsment bevált eszközeit és elveit. A nemzetközi tapasztalat is azt mutatja, hogy azok a települések, térségek, amelyek a tervezési folyamatot formális keretek közé szorítják, és e formális kereteket a projektvezetés fogalmaival írják le, jobban dokumentált, gyorsabb, hatékonyabb, és végsó soron sikeresebb projekt megvalósításra számíthatnak.

\section{Kérdések a településfejlesztési koncepció szerepéről az önkormányzati munkában}

Az alábbi kérdések célja, hogy a településfejlesztési koncepció elkészítése elótt kidomborítsa a települési stratégiával kapcsolatos gondolati csomópontokat. A kérdéssorozat számos nyitott kérdést tartalmaz, ezért ezt úgy is felfoghatjuk, mint egy beszélgetés vezérfonalát. Ez a beszélgetés átvilágítási jellegú.

A kérdéseket a település vezetói, az önkormányzat belsó szakértói önmaguknak is feltehetik, ebben az esetben önátvilágításról lehet beszélni. Az önátvilágítás olyan módszer, amely jól illeszkedik abba a folyamatba, melynek során a települések önmaguk kezébe veszik sorsukat. A kérdésekre adott válasz nem feltétlenül szól a külvilágnak. Az önátvilágítást úgy kell tekinteni, mintha a település tükröt tartana önmaga elé.

Ugyanakkor a kérdéssorozat alkalmas arra is, hogy külsó szakértó, tanácsadó vagy tervezó ennek segítségével mutasson rá a település hosszú távú fejlódésének kulcspontjaira, szúk keresztmetszeteire. 
I. táblázat.

Települési stratégia

Átvilágitási vezérfonal a településfejlesztési koncepció elkészítéséhez

1 Melyek voltak a legfontosabb változások az Önök településén az elmúlt 10-15 évben?

2 Jónak találja-e, egyetért-e azzal, ahogyan a fejlődés az Önök településén lezajlott az elmúlt 10-15 évben?

3 Ha jónak Volt-e ebben a sikerben szerepe a hosszú távú, stratégiai találja: gondolkodásnak?

4 Ha nem: Ön szerint az elmúlt 10-15 évben hogyan kellett volna megváltozni az Önök településének (ahelyett, ahogyan valójában megváltozott)?

$5 \quad$ A problémákat milyen külső körülmények okozták?

$6 \quad$ Milyen hiányosságai voltak a település hatáskörébe tartozó döntéseknek vagy a települési stratégiának?

7 Milyen változást képzel el a következő 10-15 évre

8

optimális esetben?

9

reálisan?

a körülmények kedvezőtlen alakulása esetén?

11 Kérem, fogalmazza meg és rendezze fontossági sorrendbe a településfejlesztés céljait az Önök településének esetében.

Az így megfogalmazott célok között van-e olyan cél, amelyhez az önkormányzat valamilyen most is folyamatban lévő (vagy tervezett) programot (vagy akciót) rendelt?

Ha van ilyen, akkor nevezze meg, melyek ezek célok és programok (akciók)?

14 Ha az önkormányzat el akar érni valamit az Önök településen, akkor melyek a legfontosabb eszközei? Hogyan jellemezné az önkormányzat mozgásterét? (Adópolitika, telekpolitika, lobbizás, intézményfejlesztés stb.)

$15 \mathrm{Mi}$ a fejlődés kulcsa, motorja az Önök településén?

16 Az Önök településén mi a fejlődés legfőbb akadálya, kerékkötője, legszűkebb keresztmetszete?

17 Ön szerint van-e a településüknek helyi fejlesztési stratégiája?

18 Ha van helyi Meg van-e ez fogalmazva valamilyen dokumentumban? Ha van fejlesztési ilyen dokumentum, akkor mi annak a neve, elfogadta-e a stratégia: Képviselőtestület, milyen időtávra vonatkozik? Mely pontjai kavartak esetleg vitát?

19 Ha nincs helyi Akkor hogyan érvényesül Önöknél a hosszú távú gondolkodás az fejlesztési stratégia:

Akkor hogyan érvényesü
aktuális döntésekben? 
20 Kérem, sorolja fel a település fejlődését meghatározó helyi érdekcsoportokat. Érdekcsoportonként menjünk végig az alábbi kérdéseken.

21 Érdek- Milyen döntéseket, fejleményeket, befolyásol ez az érdekcsoport csoporton- és milyen módon?

Mennyire erős, mennyire szervezett ez a csoport? Van-e olyan formálisan is bejegyzett szervezet (egyesület, alapítvány, szakmai szövetség, kamara), amely ennek a csoportnak az érdekeit fogalmazza meg? csatornája?

Vannak-e fontos szerződéses vagy érdekegyeztetési kapcsolatok az önkormányzat és a csoport egésze vagy annak egyes képviselői között?

Hogyan kérné ki a csoport véleményét egy előkészületben lévő településfejlesztési koncepcióval kapcsolatosan?

27 Van-e a településen olyan érdekcsoport, amely nem rendelkezik intézményesített képviselettel, nem hallatja hangját? Felvállalja-e az önkormányzat e csoportok érdekeinek képviseletét, és ha igen, hogyan?

28 Az elmúlt tíz évben az Önök településén kik és milyen fórumokon képviselték a hosszú távú települési érdekeket? Mivel szemben kellett ezeket az érdekeket képviselni?

A lehetőségek szükössége által meghatározott rövid távú, túlélési szemlélettel szemben? Miben nyilvánult ez meg?

Rövid távú csoportérdekekkel szemben? Milyen csoportok milyen érdekeivel szemben?

31 Van-e az Önök településének érvényes településfejlesztési koncepciója?

32 Ha nincs Mit gondol, miért nincs?

település-

33 fejlesztési koncepció:

Az Önök településén melyek lehetnének a településfejlesztési koncepció súlyponti elemei?

34 Ha van településfejlesztési

A településfejlesztési koncepciót milyen formában hozták nyilvánosságra? (Tervdokumentum, kiadvány, internetes honlap koncepció: stb.)

Az Önök településén melyek a településfejlesztési koncepció súlyponti elemei?

Egyetért-e a településfejlesztési koncepció főbb stratégiai döntéseivel? külső szakértők, tervezők segítségével? felfedezni a településfejlesztési koncepcióban? 
39

Mennyi időbe telt a koncepció elkészítése?

Mit gondol: milyen időközönként kell felülvizsgálni, szükség esetén módosítani a településfejlesztési koncepciót?

Fontos-e az Önök településén ez a dokumentum?

Ha igen: Miért fontos ez a dokumentum? Ha nem fontos: miért nem?

Az Önök településén milyen kapcsolatban áll egymással a fejlesztési koncepció és a rendezési terv?

Tartozik-e határidőkkel is ellátott program a településfejlesztési koncepcióhoz? Hol tart a program megvalósítása? Van-e felelőse a megvalósításnak? Milyen gyakran és hogyan ellenörzik a program megvalósítását?

45 Most kérem, hogy vegyük sorba az igazgatási területeket, a település vonzereje szempontjából. llyen igazgatási területek lehetnek a következök: szociális ellátás, oktatás, egészségügy, kultúra, lakásügy, infrastruktúra és közmüvek, gazdaságfejlesztés, munkahelyteremtés, turizmus, környezetvédelem, az épített környezett védelme stb.

46 Igazgatási területek összehasonlító

47 elemzése
Mely igazgatási területeket emelné ki, mint amelyek kulcsfontosságúak a település sikere, versenyképessége, vonzereje szempontjából? Miért épp ezeket?

Melyek azok az igazgatási területek, amelyek a település erősségének számítanak, mert javítják az életminőséget, és fokozzák a település vonzerejét, versenyképességét?

Melyek azok az igazgatási területek, amelyek a település gyengeségének számítanak, mert nem járulnak hozzá sem az életminőség javulásához, sem a település versenyképességéhez?

Mely igazgatási területek szerepelnek részletesen, esetleg önálló fejezetként vagy térképen is megjelenítve a település rendezési tervében?

Melyek azok az igazgatási területek, amelyek ugyan nem szerepelnek részletesen a település rendezési tervében, de fontosságuk miatt súlyponti elemet kell képezniük a településfejlesztési koncepcióban? Miért épp ezeket az igazgatási területeket említi?

Mely igazgatási területeken figyelhető meg a legnagyobb eltérés egyfelől a tervek, elképzelések, másfelöl a jelenlegi helyzet között?

Ha van ilyen eltérés, akkor milyen számszerű mutatók tükrözik a tervektöl való eltérést, elmaradást?

Mely igazgatási területeken van az önkormányzatnak nagyobb lehetősége arra, hogy helyi szempontokat érvényesítsen?

Mely igazgatási területeken van az önkormányzatnak kisebb lehetősége arra, hogy helyi szempontokat érvényesítsen? 

koncepciója?

Támaszkodhat-e a településfejlesztési koncepció egy vagy több igazgatási terület fejlesztési koncepciójára? Melyik igazgatási területre jellemző leginkább a hosszú távú, stratégiai gondolkodás?

57 Van-e az önkormányzatnak elegendő adminisztratív kapacitása, szaktudása, ereje arra, hogy...

elkészítsen egy településfejlesztési koncepciót teljes egészében? elkészítse egy településfejlesztési koncepció bizonyos munkarészeit? megakadályozza az érvényes településfejlesztési koncepcióval ellentétes döntések meghozatalát? megakadályozza az érvényes településfejlesztési koncepcióval ellentétes folyamatok elindulását?

63 Van-e elegendő munkaalkalom a településen? Mit tesz az önkormányzat a munkahelyteremtés érdekében?

65 Hogyan ösztönzi az önkormányzat vállalkozások odaköltözését, megtelepedését? Versenyképes-e a település ebből a szempontból?

Hogyan élénkíti az önkormányzat a helyi vállalkozások teremtését és növekedését? településen?

68 Van-e az Önök településének helyi gazdaságfejlesztési koncepciója?

69 Ha van helyi Ez egy hosszabb távon gondolkodó terv, vagy középtávú, esetleg gazdaság- rövidebb távú koncepció?

70 fejlesztési Tartozik-e határidőkkel is ellátott program a helyi koncepció: $\quad$ Tartozik-e határidőkkel is ellátott prograstejestési koncepcióhoz? Hol tart a program megvalósítása? Van-e felelőse a megvalósításnak?

75 Milyen külső intézményeket, szervezeteket kell figyelembe venni, amikor a település fejlődéséröl gondolkodnak? Kérem, hogy a helyi hatás ereje szerint rendezze sorba az alábbi intézményeket, szervezeteket. Konkrétan milyen és mekkora hatása van ezeknek az intézményeknek, szervezeteknek a helyi fejlesztési stratégiára? 


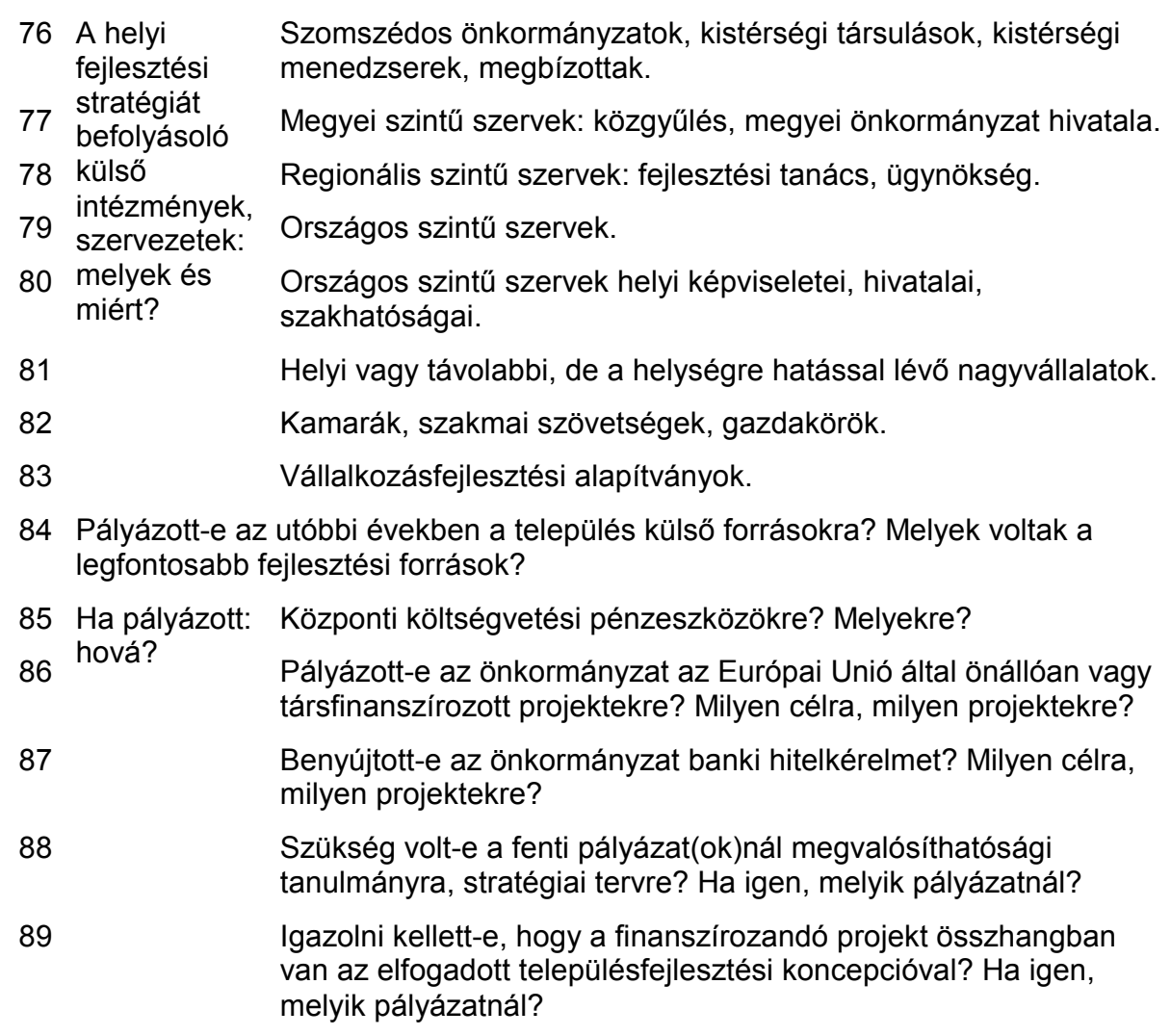

\section{A településfejlesztési koncepció-készítés folyamatának táblázatos áttekintése}

Az alább következó táblázatok a településfejlesztési koncepciót készíttetó önkormányzati munkacsoport módszertani segédletének tekinthetók, mely a teendóket - a koncepciókészítés szakaszait követve - három fó kérdés:

- mit,

- kivel és

- hogyan

kérdések köré csoportosítja. 

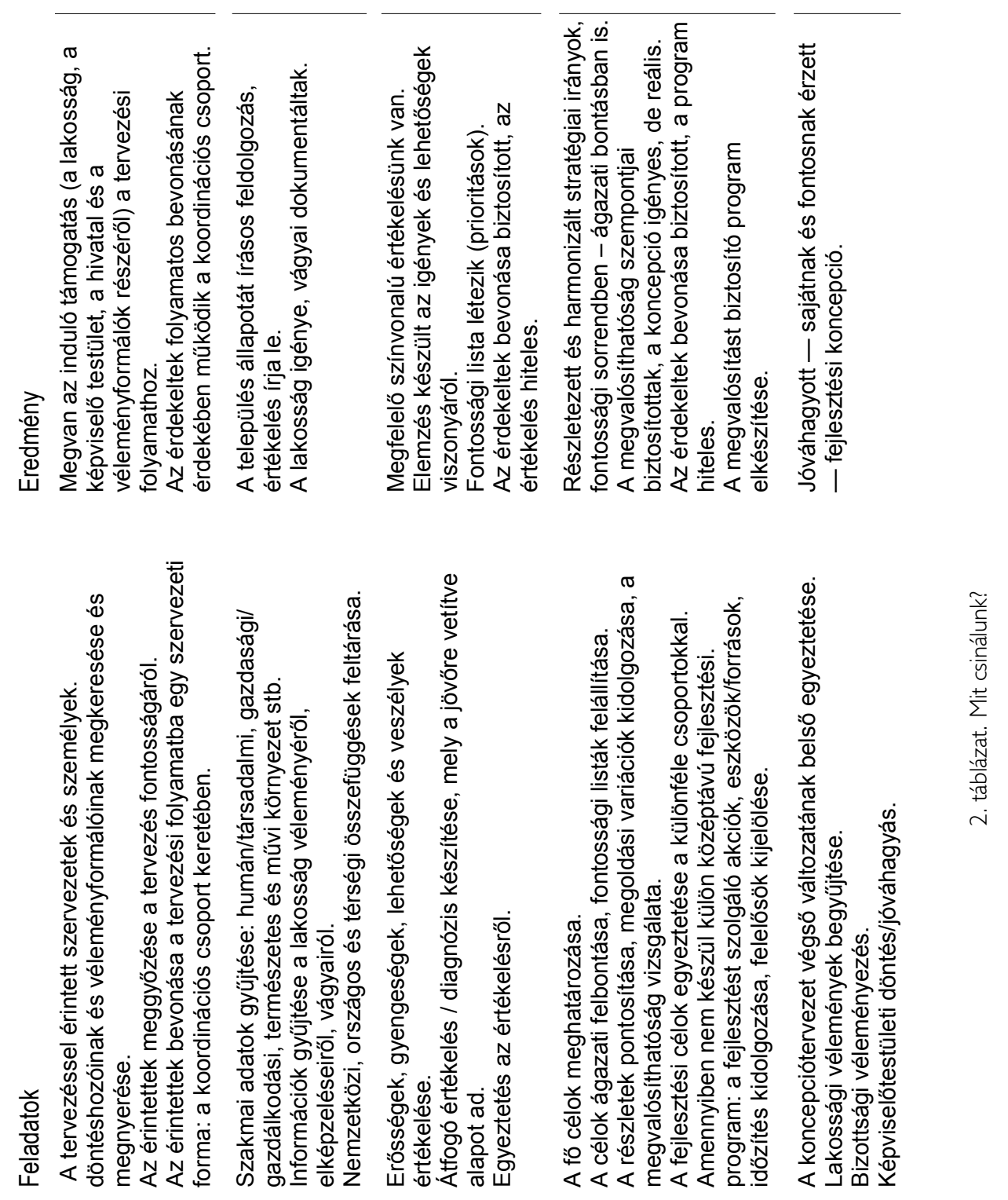

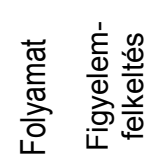
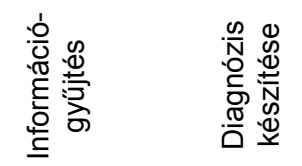

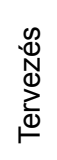

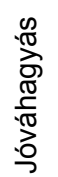




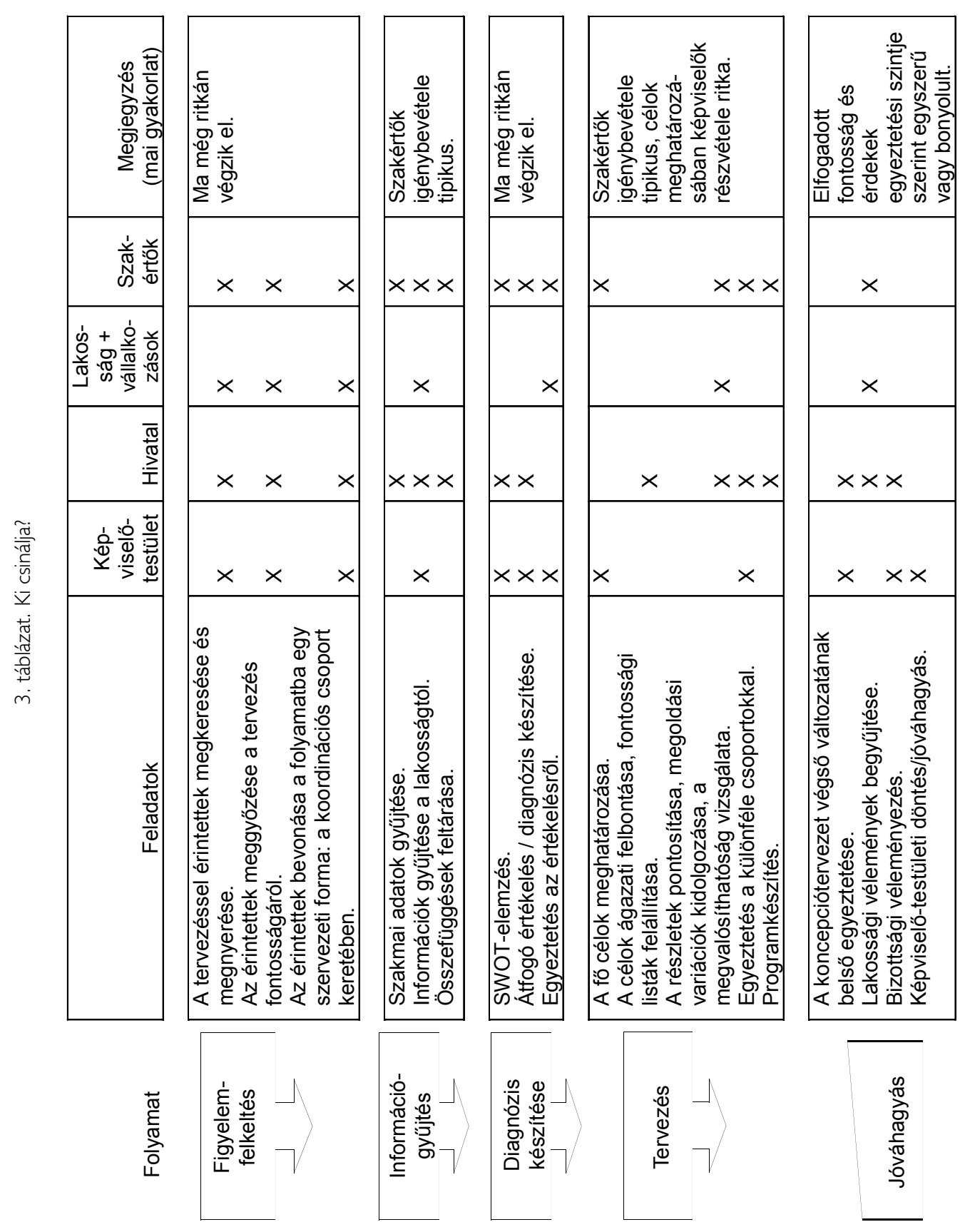




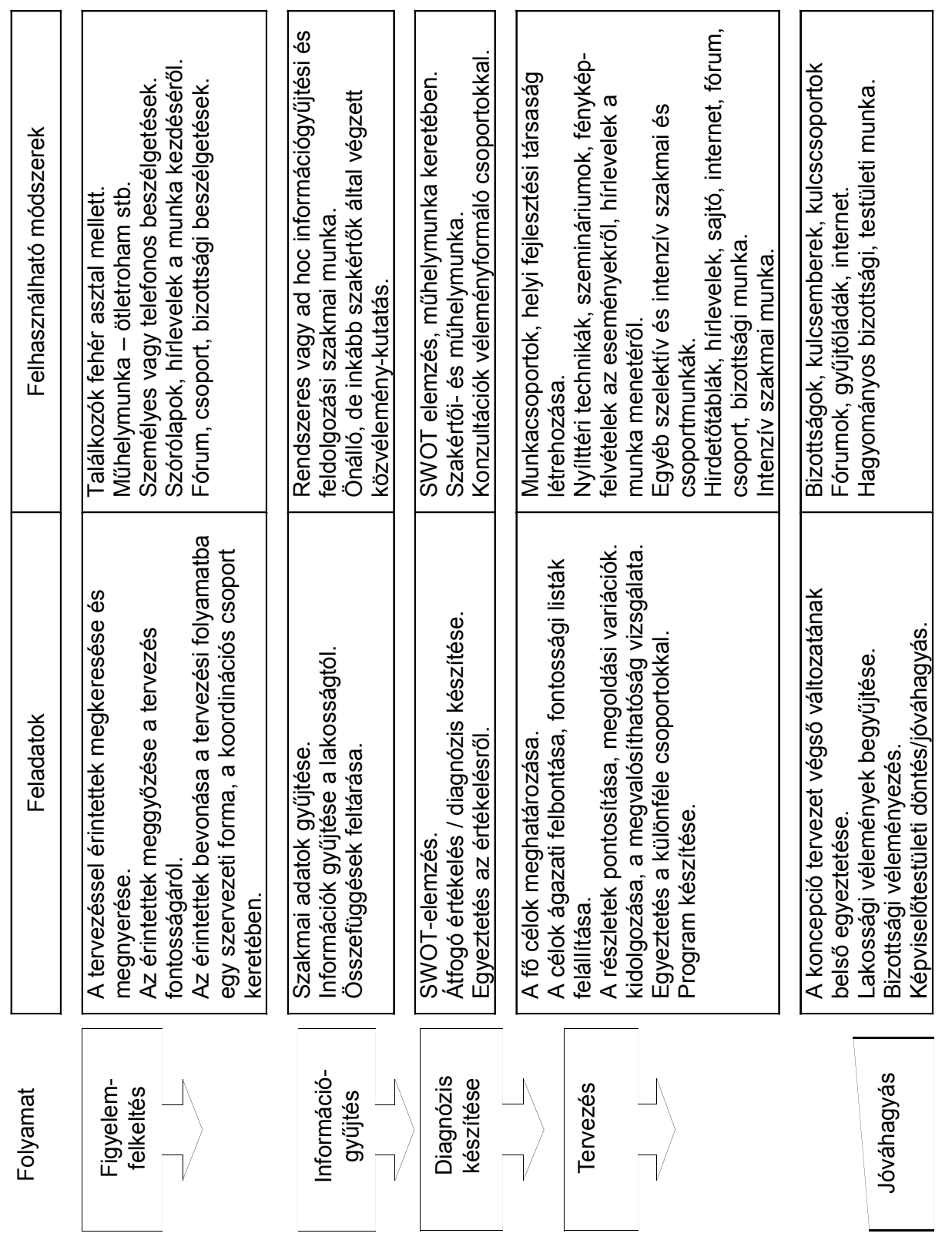




\section{A tények és a tennivalók megkülönböztetése}

Minden településfejlesztési koncepcióban fellelhetók olyan gondolatok, amelyek jellegüknél fogva

- a tényismertetéshez,

- a diagnózishoz, vagy

- a normatív részhez (a tennivalók kifejtéséhez) tartoznak.

Az egyes tervezói-kutatói iskoláktól függ, hogy ezek a stratégiai dokumentumok milyen arányban tevódnek össze a fenti múfaji elemekból.

\section{Tényismertetés}

A településfejlesztési koncepció elkészítésének megkerülhetetlen fázisa a helyzetfelmérés. Figyelembe kell venni a várható változásokat, a létezó helyi, regionális és országos koncepciókat, az ágazati és a demográfiai elórejelzéseket. A helyi és regionális adatgyújtés során számba kell venni a már meglévố dolgokat: a létezó infrastrukturális és intézményi ellátottságot.

A helyzet felmérésére alkalmazható adatgyúijtési technikák a következók:

- dokumentumelemzés, például már meglévó felmérések, koncepciók tanulmányozása;

- személyes és telefonos felmérés állampolgárok vagy cégek körében;

- szakértói interjúk készítése vállalati vagy intézményi szereplókkel;

- a Központi Statisztikai Hivatal településsoros adatainak (T-STAR) használata;

- minisztériumi szintú adatgyújtemények (például ilyen a VÁTI által összeállított TEIR-rendszer).

\section{Diagnózis}

A tények bemutatásának összegzéseként be kell mutatni az elemzók véleményét, itéletét a település lakhatóságáról, versenyképességéról. Ez tisztázó jellegú gondolkodást, távlati szemléletet igényel, hiszen figyelembe kell venni a máshol szerzett tapasztalatokat, az emberi és intézményi tényezóket. A pillanatnyi állapotokat és az elórejelzéseket szembesíteni kell a vágyakkal, elképzelésekkel. A diagnózis múfaja sok esetben úgynevezett SWOT-elemzés formáját ölti, azaz a dokumentum felsorolja vagy kifejti a települési erósségeket, gyengeségeket, lehetóségeket és a település fejlódését fenyegetó veszélyeket. 
Normatív rész (tennivalók)

A településfejlesztési koncepciótól is jogosan elvárható múfaji követelmény, hogy a tervek, célok, szándékok legyenek jól elkülönítve a tényektól. A jó településfejlesztési koncepció fóleg normatív jellegú, tehát az anyag java része nem csupán tényekról, hanem tennivalókról szól. A tények és a szándékok aránya a településfejlesztési koncepcióban meghatározó fontosságú. Mivel a koncepció normatív múfaj, ezért szükségszerú, hogy a tervek, célok, szándékok domináljanak. Nem jól használhatók azok a településfejlesztési koncepciók, amelyek megragadnak az adatok ismertetésénél. Itt, a normatív részben, azaz a tennivalók kifejtése során, a települési stratégia készítói hasonló formai kérdésekkel szembesülnek, mint a vállalati stratégák.

A fogalmi kereteket az alábbi módon érdemes megválasztani:

- tisztázni kell a célok, rész-célok, eszközök, intézkedések hierarchiáját;

- a településfejlesztési koncepciót át kell alakítani határidókkel, tennivalókkal, felelósökkel rendelkezó programmá, akcióprogrammá, akciótervvé;

- le kell szögezni, hogy miként fogják követni és értékelni a program megvalósítását (angolul: monitoring és evaluation);

- át kell tekinteni a programhoz kapcsolható kiadásokat és a finanszírozás forrásait, lehetóleg célok és eszközök szerint.

A normatív rész szükséges alkotórészei:

- a jövókép;

- a kollektív akarat;

- a helyi, regionális, országos és nemzetközi folyamatokkal való összehangolás;

- valamint a terv lebontása akcióprogramokra.

\section{A koncepció megvalósítása, a program lebonyolítása}

\section{A PROJEKT LEBONYOLÍTÁSA}

Mivel a településfejlesztési koncepció elkészítésének és megvalósításának folyamata minden esetben sokszereplós projekt formáját ölti, ezért alkalmazhatók rá a projekt menedzsment és a stratégiai tervezés általánosan, széles körben alkalmazott elvei és módszerei. Ezeknek a módszereknek jó részét a vállalati tervezés fejlódése során fejlesztették ki, és a megfeleló módosításokkal sokszor jól alkalmazhatók település esetére is. A projekt szerkezetére éppúgy nem létezik egységes minta, mint ahogy a múfaj kötöttségei is meglehetósen lazák. 
A projektvezetés módszerének során határozottan megkülönböztetjük egymástól az olyan fogalmakat, mint:

- a projekt eszközei, köztes céljai és végcéljai;

- a projekt eróforrásai (humán és tárgyi eróforrások, idó, pénz), azok forrásai és korlátai;

- a csak egymást követóen, illetve az egymással párhuzamosan végezhetó tevékenységek;

- a projekt végpontja, a projekt idótartama és a megválasztott idólépték, a projekt mérföldkövei;

- a projekt folyamata és a végtermékének tekintett szolgáltatás vagy produktum;

- az egyes rész-projektek, amelyek együttese kiadja a projekt egészét;

- a projekt figyelemmel követése, értékelése, az erról készített rendszeres jelentések.

A projektvezetés háromféle szerepló tevékenységét igényli:

- szúk vezetối csoport;

- a projekttervezó szakemberek csoportja; és

- a projekthez társuló eseti munkacsoportok.

A projekt összefüggéseinek és tartalmának pontos meghatározása után a technikai, pénzügyi és szervezeti megvalósításhoz eróforrásokat kell hozzárendelni. Világossá kell tenni az egyes szereplók státuszai közötti különbségeket: más és más feladattal néz szembe a megbízó, a tervezó és a kivitelezók.

A projekt csak akkor tekinthetó teljesnek, ha megvalósítását, hatásait folyamatosan figyelik (monitorozás), értékelik, és ennek eredményeit folyamatosan szembesítik az eredeti tervekkel, amelyeket a körülmények megváltozásakor szükség esetén módosítanak.

\section{ÖNKORMÁNYZATI KOMMUNIKÁCIÓ A LAKOSSÁGI, VÁLLALKOZÓI ÉS INTÉZMÉNYI CSOPORTOKKAL}

A stratégiaalkotási folyamat csak akkor lehet sikeres, ha maga mögött tudja a helyi vezetók, vállalkozói és más civil érdekcsoportok, az egyes lakosok és lakossági csoportok tudását, támogatását és elkötelezettségét. Különös figyelmet kell szentelni a legfontosabb területi szereplóknek, mint amilyenek a szomszédos és hasonló helyzetú önkormányzatok, az igazgatási szervek, vállalatok, kamarák, és az olyan civil szervezetek, mint a szakmai tömörülések, egyesületek, pl. iskola- 
székek, helyi érdekeltségú környezetvédelmi szervezetek stb. A koncepció sikere azon múlhat, hogy jól választották-e meg az érdekek egyeztetésének mechanizmusát. Tehát nem elég az önkormányzat szava a fejlesztési koncepció kialakításakor.

Az együttmúködés sohasem természetes vagy automatikus: ezt a folyamatot éppúgy menedzselni kell, mint a projekt egyéb fázisait. Össze kell hangolni az olyan területi szereplók tevékenységét és érdekeit, mint amilyenek az önkormányzatok, szakigazgatási szervek, egyesületek, vállalatok, szakmai tömörülések és kamarák. A koncepció-dokumentum legfóbb feladata sok esetben éppen az érdekegyeztetés fogalmi kereteinek kulturált megteremtése. Az érdekcsoportokkal való egyeztetés egyben azt is garantálja, hogy ne a tervezó találja ki, melyek a település fejlesztési céljai.

Az egyeztetés során figyelembe kell venni, hogy az egyes résztvevók különbözó gondolkodásmóddal, pillanatnyi helyzetüktól függó sajátos logikával közelítenek a tervezési folyamathoz. A résztvevói logikák a következóképpen csoportosíthatók:

- Szervezeti logika: minden egyes szervezetnek megvannak a funkciói, melyeket hierarchikus szervezeti rendszerben látnak el. Ez a logika alkalmasabb az ismétlódó, mindennapi akciókra, mint a projektvezetésre. Gyakran gátol, a partneri együttmúködésnél elóbbrevalónak tekinti a hatalma megvédését.

- Hálózati logika: leginkább a személyek közötti erós kapcsolatokra épít, ami a szervezeti logikát gyakran felborítja.

A lakosság bevonásának eszközei a következók:

- nyilvános gyúlések;

- iskolázás és felnóttképzés;

- faluértékelés (angolul: village appraisal, németül Dorfbewertung); ez egy gazdasági - társadalmi - környezeti témákat felöleló felmérési folyamat, amely cselekvési tervhez vezet;

- vásárok, rendezvények;

- média és telekommunikáció.

A lakosság bevonásának elósegítésére a következó szervezeti keretek képzelhetók el:

- helyi fejlesztési megbízott kinevezése;

- fórum vagy hálózat alapítása;

- fejlesztési társulások alapítása. 
A helyi érdekcsoportok bevonása valamennyi nemzetközi szervezet - így az EU, az OECD és a Világbank - stratégiaalkotási ajánlásaiban kulcsszerepet játszik. A koncepciót tehát - pusztán attól, hogy egy választott testület elfogadta - nem feltétlenül tekintik legitimnek. Ehhez még szükséges a folyamatos egyeztetés is.

A bevonás módszerei a stratégiai folyamat egyes fázisaiban mindig mások.

- A stratégiaalkotási projekt kezdeti fázisa döntó fontosságú, mert ez a motiváció és a figyelemfelkeltés ideje. Ekkor minél szélesebb lakossági rétegeket kell tájékoztatni. Ebben a fázisban a sikerrel alkalmazott eszközök a következók: úgynevezett „Nyitott ajtók napja” rendezvény szervezése, vándorkiállítások, médiamunka.

- A stratégiaalkotási projekt második fázisa: a probléma elemzése és a fejlesztési projekt megtervezése. Ekkor szelektívebb és intenzívebb módszerek ajánlottak. Ilyen módszer például szakosodott munkacsoportok, helyi fejlesztési társaságok létrehozása.

- A harmadik fázis: a fejlesztési projekt megvalósítása. Ehhez a tanácsadás, a technikai segítség, a képzés és a pénzügyi támogatás eszközei tartoznak. 
